PRINT ISSN 1119-8362

Electronic ISSN 1119-8362
Full-text Available Online at

https://www.ajol.info/index.php/jasem

http://ww.bioline.org.br/ja
J. Appl. Sci. Environ. Manage.

Vol. 24 (11) 1873-1876 November 2020

\title{
Market Opportunities and Profitability of Tree Crop Planting in Nigeria
}

\section{OLUGBIRE, OO; *ORUMWENSE, LA; OLOBA, OG; OKE, OS; OYANIYI, T; JATTO, KA}

\author{
Forest Economics and Extension Services Department, Forestry Research Institute of Nigeria, P.M.B. 5054, Jericho Hills, Ibadan, Oyo \\ State, Nigeria \\ *Corresponding Author Email: adetejuf@yahoo.com; Tel: +2348062549670
}

\begin{abstract}
Investing in trees offer financial and social returns for years to come and it is a lucrative long-term investment in Nigeria. Despite the substantial gain on investment in tree planting, only few people are still involved in the business. This paper analyzed the profitability of investment in tree crop planting for income generation. Benefit Cost Ratio (BCR) and Net Present Value (NPV) were calculated to determine the financial viability of tree crop planting. The

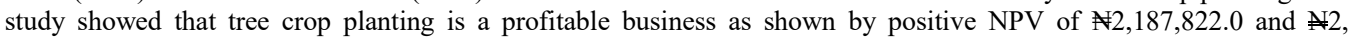
782,214.97 for Tectonia grandis and Moringa oleifera plantations respectively, after 10-years of maturation and harvesting at $14 \%$ discount rate with a B/C Ratio of 1.97 and 1.6 respectively. Also, NPV of $\$ 1,575,487.10$ for a 5-year small scale private nursery establishment with a B/C Ratio of 2.79 at a $14 \%$ discount rate also confirm that the investment on nursery establishment is highly profitable. It is recommended that with adequate support and incentives, farmers can take advantage of these opportunities and invest in nursery enterprise and tree crop sub-sector of the economy.
\end{abstract}

\section{DOI: https://dx.doi.org/10.4314/jasem.v24i11.5}

Copyright: Copyright (C) 2020 Olugbire et al. This is an open access article distributed under the Creative Commons Attribution License (CCL), which permits unrestricted use, distribution, and reproduction in any medium, provided the original work is properly cited.

Dates: Received: 23 September 2020; Revised: 30 October 2020; Accepted: 07 November 2020

Keywords: Market opportunities, Tree planting, BCR, NPV

Tree crop planting have been proven to provide a range of restoration systems to degraded environments and lands with positive effects on food production, ecosystem health and profitability (Program on Forests, 2011). Forest trees provide materials for domestic construction, furniture, cosmetic and mining industries, for growing urban populations, and in some countries are significant sources of export revenue (World Bank, 2014). Investing in trees offer financial and social returns for years to come and it is a lucrative long-term investment. Trees increase in value exponentially as they grow, with relatively low startup costs, low labour costs, and low maintenance costs (Ohaga, 2019). The loss of tropical forest resources on which millions of rural people depend has been rapid over the past century. An estimated 350 million hectares of tropical forests have been deforested while 500 million hectares of secondary and primary topical forests have been degraded (Le et al., 2011). Tree planting (both reforestation and afforestation) can help reverse some of the more severe impacts of forest loss and degradation on rural communities in the tropics by providing secure access for local people to a range of forest products, including fuelwood and non-timber forest products; improved hydrological regulation and nutrient cycling; providing more diverse and better connected habitats, thus supporting more biological diversity; and options to increase the resilience and adaptability of existing agricultural systems (Maginnis and Jackson, 2002).

In addition to their potential financial returns, trees help fight against climate change by sequestering carbon, preventing erosion and water runoff, while certain varieties like Moringa spp. can improve land fertility by fixing nitrogen in the soil (Ohaga, 2019). Tree planting also strengthens the resilience of people and communities to climate change (Program for Forests, 2011).

To preserve the livelihoods of rural communities in the tropics, and for global climate change mitigation, it is clear that tree planting is necessary (Le et al., 2011). Small-scale forest plantations provide a range of benefits to rural communities, including fuelwood, fodder and wood for building and everyday uses, as well as environmental and amenity benefits (Nawir et al., 2007). Currently, unemployment is becoming one of the serious problems in Nigeria. Therefore, smallscale nursery production plays a great role for job creation and poverty reduction combined with adding to both ecological and aesthetic values (Molla et al., 2020). The importance of trees on farm land is therefore well established and promoted by many development agencies (Oli et al., 2015). The agroforestry value chain has a lot of opportunities, whether in timber felling and lumber processing, 
transportation, construction, or plant breeding and tree nursery operations. There exist in Nigeria opportunities for tree crops seedling production to meet estimated demand (Adepoju, 2015). Market trends are promising for a wide-range of tree-based crops, including timber, fruits, fiber, fodder, medicinal, and agroforestry systems.

Based on their economic uses, tree crops planting for marketing can be done through: Commercial tree planting e.g. Tectona grandis (Teak), Gmelina spp., Amenity planting purpose e.g. Hildegardia barteri, Tree planting for conservation purpose e.g. Khaya senegalensis, Nauclea spp., Tree planting for multiple uses e.g. Moringa oleifera, Fruit trees e.g. Irvingia spp., Garcinia kola, Fibre trees (Sisal).

However, despite the substantial gain on investment in tree planting, only few people are still involved in the business. This paper therefore, analyzed the profitability of investment in tree crop planting for income generation. Gross Margin (GM), Benefit- Cost Ratio (BCR) and Net Present Value (NPV) were calculated to determine the financial viability of tree crop planting.

\section{MATERIALS AND METHODS}

Data collection: The data for this study was collected from both primary (interview method) and secondary data sources. This include interview of experts/technical officers in the field of forestry from the Department of Forestry, University of Ibadan and Department of Sustainable Forest Management, Forestry Research Institute of Nigeria.

The existing literature on small scale nursery production according to Larinde and Santus, 2014 was reviewed in this paper.

Data Analysis: The data were analyzed using financial analytical procedures such as profitability analysis. Profitability analysis of selected tree crop plantation and nursery establishment: The profitability of the selected tree crop plantation was calculated using the formula below:

$$
\begin{gathered}
\mathrm{GM}=\mathrm{TR}-\mathrm{TC}---1 \\
N P V=\sum_{t=1}^{n}\left(\frac{B_{t}-C_{t}}{(1+i)^{t}}\right)--2 \\
\mathrm{BCR}=\frac{\sum_{t=1}^{n}\left(\frac{B_{t}}{(1+i)^{t}}\right)}{\sum_{t=1}^{n}\left(\frac{C_{t}}{(1+i)^{t}}\right)}=\frac{P V B}{P V C}--3
\end{gathered}
$$

Where; $\mathrm{B}=$ benefit, $\mathrm{C}=$ cost, $\mathrm{t}=$ time, $\mathrm{i}=$ interest rate; $\mathrm{BCR}=$ Benefit Cost Ratio, NPV $=$ Net Present Value;
$\mathrm{GM}=$ Gross Margin, $\mathrm{TR}=$ Total Revenue and $\mathrm{TC}=$ Total Cost1

The cost-benefit ratio $(\mathrm{B} / \mathrm{C} \mathrm{R})$ is determined by dividing the revenue generated in the plantation by the costs incurred. If $\mathrm{B} / \mathrm{C} \mathrm{R}$ is $>1$, then the enterprise is operating at a profit but if $\mathrm{B} / \mathrm{CR}<1$, it is a nonprofitable venture.

Discount rate: Discount rate of $14 \%$ was used in the analysis because that is the present lending rate in Nigeria (NLR, 2020).

\section{RESULTS AND DISCUSSION}

Profitability of Investment in Tree Crop Planting: The investment analysis on Tables 1 and 2 showed that tree crop planting is a profitable venture. For example, Table 1 and Table 2 showed that $\$ 10,452,000$ and $4,565,341.2$ will be earned as profit from plantation establishment of one hectare of Tectonia grandis and Moringa oleifera plantation respectively after ten years of maturation and harvesting. The estimated value of $\$ 2,187,822.00$ and $\$ 2,782,214.97$ will also be realized as profit if $\$ 10,452,000$ and $\$ 4,565,341.2$ is brought to its present worth. Furthermore, the Benefit Cost analysis of 1.97 and 1.6 in Table 1.

Table 2 respectively showed that for every one million naira invested the return will be one million nine hundred thousand naira on Tectonia grandis plantation establishment and one million six hundred thousand naira on Moringa oleifera plantation establishment. This implies that the investment on plantation establishment is highly profitable.

Table 3 showed the projected cash flow for a 5-year small scale private plant nursery enterprise establishment at $14 \%$ discount rate as adapted from Larinde and Santus (2014) research.

The total benefit-cost ratio of the enterprise was 2.79 . Since the cost benefit ratio for the past five years is above 1 , this means that small scale private plant nursery enterprise is a viable venture that one can engage in even if one cannot invest in tree crop plantation.

Also, according to Larinde and Santus (2014), small scale private plant nursery enterprise is a viable venture that one can engage in for income generation and as means of conservation of plant species as well as for the control of environmental problem like climate change. 
Market Opportunities and Profitability of Tree Crop Planting.....

Table 1: Projected cash flow for a Ten-Year-Rotation of Tectonia grandis Plantation Establishment on one hectare of land at FRIN arboretum using $14 \%$ as discount rate

\begin{tabular}{lllll}
\hline Year & $\begin{array}{l}\text { Costs in } \\
\text { Naira }\end{array}$ & $\begin{array}{l}\text { Benefits } \\
\text { in Naira }\end{array}$ & $\begin{array}{l}\text { Net Present } \\
\text { Value (Benefits) }\end{array}$ & $\begin{array}{l}\text { Net Present } \\
\text { Value (Costs) }\end{array}$ \\
\hline 1 & 201000 & 180000 & 157860 & 176277 \\
2 & 626000 & 180000 & 138420 & 481394 \\
3 & 626000 & 180000 & 121500 & 422550 \\
4 & 526000 & 180000 & 106560 & 311392 \\
5 & 476000 & 240000 & 124560 & 247044 \\
6 & 350600 & 240000 & 109440 & 159873.6 \\
7 & 350600 & 240000 & 96000 & 140240 \\
8 & 350600 & 240000 & 84240 & 123060.6 \\
9 & 350600 & 240000 & 73920 & 107984.8 \\
10 & 350600 & 12740000 & 3439800 & 94662 \\
Total & $\mathbf{4 2 0 8 0 0 0}$ & $\mathbf{1 4 6 6 0 0 0 0}$ & $\mathbf{4 4 5 2 3 0 0}$ & $\mathbf{2 2 6 4 4 7 8}$ \\
Gross Margin $(\mathbf{G M})=\mathbf{A 1 0 , 4 5 2 , 0 0 0 ;} \mathbf{~ N P V}=\mathbf{2 2 , 1 8 7 , 8 2 2 . 0 0 ; ~ B C R}=\mathbf{1 . 9 7}$ \\
\hline
\end{tabular}

Table 2: Projected cash flow for a Ten-Year-Rotation of Moringa oleifera Plantation Establishment on one hectare of land at FRIN arboretum using $14 \%$ as discount rate

\begin{tabular}{|c|c|c|c|c|}
\hline Year & $\begin{array}{l}\text { Benefits in } \\
\text { Naira }\end{array}$ & $\begin{array}{l}\text { Costs in } \\
\text { Naira }\end{array}$ & $\begin{array}{l}\text { Net Present } \\
\text { Value (Benefits) }\end{array}$ & Net Present Value (Costs) \\
\hline 1 & 2246808 & 1399336.8 & 1970450.616 & 1227218.374 \\
\hline 2 & 1912212 & 1191968.4 & 1470491.028 & 916623.6996 \\
\hline 3 & 1627620 & 1014568.8 & 1098643.5 & 684833.94 \\
\hline 4 & 1385098.8 & 863395.2 & 819978.4896 & 511129.9584 \\
\hline 5 & 1178857.2 & 734984.4 & 611826.8868 & 381456.9036 \\
\hline 6 & 1003419.6 & 625477.2 & 457559.3376 & 285217.6032 \\
\hline 7 & 853815.6 & 532221.6 & 341526.24 & 212888.64 \\
\hline 8 & 798672 & 452970 & 280333.872 & 158992.47 \\
\hline 9 & 618411.6 & 385483.2 & 190470.7728 & 118728.8256 \\
\hline 10 & 526315.2 & 385483.2 & 142105.104 & 104080.464 \\
\hline Total & 12151230 & 7585888.8 & 7383385.847 & 4601170.878 \\
\hline \multicolumn{5}{|c|}{ Gross margin $=4,565,341.2 ; \mathrm{NPV}=2,782,214.97 ; \mathrm{BCR}=1.6$} \\
\hline
\end{tabular}

Table 3: Projected cash flow for a 5-year small scale private plant nursery enterprise establishment at $14 \%$ discount rate

\begin{tabular}{|c|c|c|c|c|c|}
\hline Year & Costs ( & Revenue (A) & $\begin{array}{l}\text { Discounted } \\
\text { Costs ( })\end{array}$ & $\begin{array}{l}\text { Discounted } \\
\text { Revenue ( })\end{array}$ & $\begin{array}{l}\text { Net present } \\
\text { value (N) }\end{array}$ \\
\hline 1 & 351000 & 390,000 & $307,897.20$ & $342,108.00$ & $34,210.80$ \\
\hline 2 & 176000 & 500,200 & $135,432.00$ & $384,903.00$ & $249,471.90$ \\
\hline 3 & 210000 & 750,000 & $141,750.00$ & $506,250.00$ & $364,500.00$ \\
\hline 4 & 256000 & 980,000 & $151,577.60$ & $580,258.00$ & $428,680.40$ \\
\hline 5 & 270000 & $1,230,000$ & $140,238.00$ & $638,862.00$ & $498,624.00$ \\
\hline Total & $1,263,000$ & $3,850,200$ & $876,894.80$ & 2,452,381.00 & $1,575,487.10$ \\
\hline \multicolumn{6}{|c|}{$\mathrm{GM}=2,587,200 ; \mathrm{NPV}=1,575,487.10 ; \mathrm{BCR}=2.79$} \\
\hline
\end{tabular}

Conclusion: An important theme that runs through the above discussion is that investments opportunities abound for tree crop development and processing in Nigeria. Forest-based businesses often provide substantial direct or indirect employment and income for those who are engaged in it. Tree based business has the potential to contribute significantly to the economic growth and development of the country. Therefore, with adequate support and incentives, farmers can take advantage of these opportunities and invest in tree crop sub-sector of the economy.

\section{REFERENCES}

Adepoju, A (2015). Investment Opportunities for Tree Crops Development, Processing and Marketing in Nigeria. J. Poverty. Invest. Develop. 7:23-29.
Larinde, SL; Santus, R (2014). Assessment of SmallScale Private Plant Nursery Enterprise in Port Harcourt, Rivers State. Global J. Biosci. BioTech. 3(3):301-311

Le, HD; Smith, C; Herbohn, J; Harrison, S (2011). More than just trees: Assessing reforestation success in tropical developing countries. J. Rural Stud. 28(1):5-19.

Maginnis, S; Jackson, W (2002). Restoring forest landscapes.

From http://cmsdata.iucn.org/downloads/restoring_fore st_landscapes.pdf (accessed 15.07.10).

Molla, M; Abtew, AA; Tebkew, M (2020). Socioeconomic contributions of small-scale private urban tree nurseries in Gondar and 
Bahirdar Cities. Cogent Food \& Agriculture, 6:1, DOI: $\underline{10.1080 / 23311932.2020 .1785104}$

Nigeria Lending Rate (NLR) (2020). Nigeria Lending Rate1961-2020 Data. Trading Economics. Accessed https://tradingeconomics.com/nigeria/lendingrate $(04 / 08 / 2020)$.

Ohaga, JB (2019). Social Entrepreneurs: Invest in Trees. One Acre Fund 2019 Annual Report. Accessed on https://oneacrefund.org/blog/socialentrepreneurs-invest-in-trees/
Program on Forests (PROFOR). 2011. Investing in Trees and Landscape Restoration in Africa: Overview. Washington, DC: World Bank.

World Bank Report (2014). Forests, Trees, and Woodlands in Africa: An Action Plan for World Bank Engagement. Accessed on August 7, 2020 on

https://openknowledge.worldbank.org/bitstream/ handle/10986/11927/730260REPLACEM0tion0 Plan06014012web.pdf? sequence $=1$ 